\title{
West Nile virus infection and diplopia: a case report and review of literature
}

This article was published in the following Dove Press journal:

International Journal of General Medicine

21 May 2013

Number of times this article has been viewed

\author{
Udip Dahal' \\ Neville Mobarakai' \\ Dikshya Sharma² \\ Bandana Pathak' \\ 'Department of Medicine, Staten \\ Island University Hospital, Staten \\ Island, New York, NY, USA; \\ ${ }^{2}$ Department of Medicine, Nepalgunj \\ Medical College, Banke, Nepal
}

\begin{abstract}
West Nile virus is a neurotropic virus transmitted to humans via an infected mosquito bite. The increase in the incidences and fatalities of West Nile virus disease has made West Nile virus an important pathogen. Here we describe a case of a 65 -year-old man with fever and diplopia presenting to the emergency department during a fall season and who was later diagnosed with West Nile virus infection. Diplopia is an uncommon manifestation of West Nile virus and recognition of the different modes of presentation, especially the uncommon ones like diplopia, will aid in the diagnosis of this emerging infectious disease.

Keywords: West Nile virus, diplopia, ocular manifestations, infectious disease, Flaviviridae
\end{abstract}

\section{Introduction}

West Nile virus (WNV), a single stranded virus, is one of several mosquito-borne neurotropic members of the Japanese encephalitis (JE) serogroup of the genus Flavivirus (family Flaviviridae) and is maintained and amplified in an enzootic system between mosquitoes and birds; mammals (including horses and humans) are incidental "dead-end" hosts. ${ }^{1,2}$ WNV has an incubation period of 2 to 14 days and is mainly transmitted to humans through mosquito bites.

Since its first introduction in New York City in 1999, WNV has spread rapidly across the USA. By 2012, more than 36,000 cases of WNV disease had been reported to the Center for Disease Control (CDC) resulting in more than 1500 deaths within the United States. ${ }^{3}$ Historically WNV infections were mild, but the more severe and fatal neurological disease seen in humans in the recent epidemics have suggested that a more virulent virus genotype has emerged which could be a significant public health burden. ${ }^{4}$ With an increase in the number of cases of WNV disease the spectrum of its clinical presentation has become broader and familiarity with the relatively infrequent mode of presentation is essential.

The purpose of this article is to present a case of WNV infection presenting with an uncommon symptom of diplopia, discuss the possible differential diagnosis of diplopia useful to a general physician, and then review the ocular manifestations of WNV infection.

\section{Case presentation}

A 65-year-old right-handed male presented to the emergency department and was treated as an inpatient with acute onset of diplopia which had persisted for 4 days, which resolved on covering either eye. Three days after onset of diplopia he complained
Department of Medicine, Staten Island University Hospital, 475 Seaview Avenue, Staten Island, New York, NY, USA

Email drudip@gmail.com 
of intermittent fevers, chills and dizziness. Dizziness was perceived as the room spinning and was associated with holocephalic headache upon coughing. He also complained of fatigue and generalized weakness. He had travelled to Mexico 6 weeks prior with a stay of 9 days, and had a history of mosquito bites while working in his backyard in Staten Island about a month before presentation. He denied any blurry vision, ocular pain, red eye, photophobia, nausea, vomiting, abdominal pain, chest pain, shortness of breath, rashes, dysarthria, dysphonia, weakness, or numbness.

His medical history was significant for hypertension, recurrent deep venous thrombosis (2004 and 2011), colon carcinoma with metastasis to liver (2003) treated with chemotherapy (last cycle 2004) and colon and right liver lobe resection. Daily home medications included aspirin, Coumadin $^{\circledR}$, pravastatin, and losartan. His social, family, and allergy history were unremarkable.

On physical examination, his vitals were normal except for a temperature of $102^{\circ} \mathrm{F}$. His neurological examination revealed normal sensation and strength, normal reflexes and cerebellar function. No meningeal signs were present. Visual acuity was 20/25 in both eyes. Confrontation visual fields, ocular motility, and optic disc were within normal limits. Ophthalmologist evaluation revealed nystagmus on supraduction. Other physical examination findings were unremarkable.

Computed tomography of orbits and sinuses were normal, as well as MRI of the brain with IV contrast, except for a chronic lacunar infarct on the left thalamus. An echocardiogram revealed no vegetations. Results of his laboratory studies are shown in Tables 1 and 2.

The patient's hospital stay was unremarkable. Diplopia resolved on second hospital day, and fatigue and weakness gradually improved. One month after discharge from the hospital the patient's fatigue was almost resolved and he was able to carry out his regular household activities without problems.

\section{Discussion}

Information on ocular manifestations of WNV infection come mainly from case reports published since February 2003. ${ }^{5}$ The prevalence of ocular involvement in WNV is unknown because ocular manifestations are generally transient and self-limited., ${ }^{5,6}$ In one population-based study of hospitalized patients conducted in Colorado during the 2003 epidemic of WNV, $26 \%$ of patients in the West Nile meningitis group had visual disturbance, compared to $18 \%$ in the West Nile encephalitis group. ${ }^{7}$ Bulbar dysfunction (dysarthria
Table I Laboratory data

\begin{tabular}{|c|c|c|}
\hline Variable & Reference range & On admission \\
\hline Hemoglobin (g/dL) & $14-18$ & 13.9 \\
\hline White cells (per $\mathrm{mm}^{3}$ ) & $4800-10,800$ & 10,600 \\
\hline \multicolumn{3}{|l|}{ Differential count (\%) } \\
\hline Neutrophils & & 89.6 \\
\hline Lymphocytes & & 5.8 \\
\hline Monocytes & & 4.1 \\
\hline Platelets (per $\mathrm{mm}^{3}$ ) & $130,000-400,000$ & 97,000 \\
\hline Prothrombin time (seconds) & $9.95-12.87$ & 31.2 \\
\hline $\begin{array}{l}\text { Activated prothrombin time } \\
\text { (seconds) }\end{array}$ & $24.3-35.1$ & 31.2 \\
\hline International normalized ratio & & 2.6 \\
\hline Sodium (mmol/L) & $135-146$ & 134 \\
\hline Potassium (mmol/L) & $3.5-5$ & 4.3 \\
\hline Chloride (mmol/L) & $98-110$ & 101 \\
\hline Carbon dioxide (mmol/L) & $17-32$ & 24 \\
\hline Urea nitrogen $(\mathrm{mg} / \mathrm{dL})$ & $10-20$ & 23 \\
\hline Creatinine $(\mathrm{mg} / \mathrm{dL})$ & $0.7-1.5$ & 1.35 \\
\hline Glucose (mg/dL) & $70-110$ & 123 \\
\hline Total protein (g/dL) & $6-8$ & 6.9 \\
\hline Albumin $(g / d L)$ & $3-5.5$ & 3.8 \\
\hline Total bilirubin (mg/dL) & $0.2-1.2$ & 1.5 \\
\hline Direct bilirubin $(\mathrm{mg} / \mathrm{dL})$ & $0-0.2$ & 0.26 \\
\hline Alkaline phosphatase (IU/L) & $30-115$ & 57 \\
\hline $\begin{array}{l}\text { Aspartate aminotransferase } \\
\text { (IU/L) }\end{array}$ & $0-41$ & 18 \\
\hline Alanine aminotransferase (IU/L) & $0-45$ & 18 \\
\hline Calcium $(\mathrm{mg} / \mathrm{dL})$ & $8.5-10.1$ & 8.8 \\
\hline Blood culture & & No growth \\
\hline Urine culture & & No growth \\
\hline Rheumatoid factor (IU/mL) & $<14$ & $\mathrm{II}$ \\
\hline Anti-dsDNA antibody & Negative & Negative \\
\hline Antinuclear antibody & Negative at $<\mathrm{I}: 40$ & Speckled at I:80 \\
\hline ESR (mm/hour) & $0-10$ & 66 \\
\hline Acetylcholine receptor antibody & & Negative \\
\hline Voltage gated calcium channel & & Negative \\
\hline RPR test & & Nonreactive \\
\hline HIV antibody test & & Negative \\
\hline
\end{tabular}

Abbreviations: ESR, erythrocyte sedimentation rate; RPR, rapid plasma reagin; HIV, human immunodeficiency virus.

and dysphagia) and focal motor abnormalities including cranial nerve palsies were more frequent in patients with West Nile encephalitis. ${ }^{7}$ Some of the common intraocular manifestations described include: chorioretinitis, uveitis without focal lesions, occlusive retinal vasculitis, optic neuritis, optic atrophy, disc edema, retinal hemorrhages, and vitreous inflammation. ${ }^{8-10}$ Chorioretinal lesions involving both eyes is the most common ocular manifestation. ${ }^{6}$ Most of these patients either do not have symptoms, have mild blurry vision, or a decrease in visual acuity. ${ }^{11}$ The clinical course is self-limited although their long term effects are unknown. ${ }^{6}$ Patients with more serious ocular lesions (ie, optic atrophy, extensive chorioretinal lesions, retinal vasculitis, and occlusion) may result in substantial visual loss and persistent 
Table 2 Cerebrospinal fluid analysis

\begin{tabular}{|c|c|c|}
\hline Variable & Reference range & Day 5 of Admission \\
\hline Appearance & & Colorless, clear \\
\hline Red cells (per mm³) & 0 & 0 \\
\hline White cells (per mm³) & $0-5$ & 4 \\
\hline Protein $(\mathrm{mg} / \mathrm{dL})$ & $15-45$ & 67.3 \\
\hline Glucose (mg/dL) & $45-75$ & 49 \\
\hline Cytology & & $\begin{array}{l}\text { Rare atypical single } \\
\text { cells favoring atypical } \\
\text { lymphocytes }\end{array}$ \\
\hline Gram stain & & No organisms \\
\hline Acid-fast bacilli smear & & No organisms \\
\hline $\mathrm{KOH}$ prep & & Negative \\
\hline India Ink & & Negative \\
\hline \multicolumn{3}{|l|}{ Cultures } \\
\hline Routine & & No growth \\
\hline Fungal & & No growth \\
\hline Mycobacterial & & No growth \\
\hline Cryptococcal antigen & & Negative \\
\hline Borrelia burgdorferi DNA & & None detected \\
\hline \multicolumn{3}{|l|}{ on PCR } \\
\hline HSV $I$ and 2 DNA on PCR & & None detected \\
\hline VDRL test & & Nonreactive \\
\hline $\begin{array}{l}\text { Angiotensin converting } \\
\text { enzyme (U/L) }\end{array}$ & $<15$ & II \\
\hline Myelin basic protein (UG/L) & $0-4$ & $<2$ \\
\hline WNV IgM & $<0.9$ & 5.49 \\
\hline WNV IgG & $<1.3$ & 2.55 \\
\hline
\end{tabular}

Abbreviations: HIV, human immunodeficiency virus; $\mathrm{KOH}$, potassium hydroxide preparation; PCR, polymerase chain reaction; HSV, herpes simplex virus; VDRL, venereal disease research laboratory; WNV, West Nile virus; WNVI, West Nile virus infection.

visual field deficit. ${ }^{12,6}$ Hematogenous dissemination of virus seeding the choroid, and direct spread of the virus from the central nervous system to retina, retinal pigment epithelium, and choroid through optic nerve have been thought to cause chorioretinitis. ${ }^{11}$ Diabetes or age greater than 50 years are risk factors for more serious ocular manifestations of WNV infection. ${ }^{6}$ Solid organ transplantation increases the likelihood of developing WNV disease, whereas homozygosity for a deletion in chemokine receptor type 5 (CCR5) gene increases the risk for symptomatic infection and death from WNV. ${ }^{13}$ The latter may be particularly important in patients with human immunodeficiency virus (HIV) who are on CCR5 antagonist therapy. ${ }^{14}$

Diplopia as a clinical presentation of WNV is very rare and could be related to cranial nerve involvement. In a retrospective case series of 14 eyes in 7 patients with WNV infection, sixth cranial nerve palsy was reported in one patient (7.1\%). ${ }^{6}$ In another case series the seventh cranial nerve was found to be involved. ${ }^{15}$ Cases of bilateral sixth nerve palsy and combination of both abducens and facial nerve have been reported. ${ }^{16,17}$ Pepperell et al listed eight patients with diplopia or ophthalmoplegia out of 64 patients with WNV infection. ${ }^{18}$ Miller and Liang in 2003, and Jensen in 2010, have described WNV cases presenting as diplopia. ${ }^{19,20}$ In one of the autopsy results of four patients with WNV reported by Sampson et al, two had focal mononuclear inflammation in the cranial nerve roots of medulla. ${ }^{21}$

\section{Differential diagnosis of diplopia}

Our patient who was immunocompromised (previous history of cancer) and had a history of mosquito bite prior to his travel to Mexico, presented with sudden onset persistent diplopia, followed by fever, chills, and headache. A crucial step in the evaluation of new onset diplopia in an immunocompromised host is to rule out serious underlying neurological disease processes. Distinguishing monocular diplopia (where patient sees double with only one eye open) from binocular diplopia (where patient sees double only when both of his eyes are open) is important since binocular diplopia could be the result of serious underlying etiologies like aneurysm, stroke, neoplasm etc. It is essential to contemplate a broad differential diagnosis initially so that potentially life-threatening, but treatable conditions are ruled out. Fever, headache, and focal neurological signs like diplopia increase the suspicion of meningitis since infections that involve the basal meninges may lead to cranial neuropathies. ${ }^{22}$ Risk of cavernous sinus thrombosis increases with facial infections that may present with fever, headache, proptosis, and ocular motor palsies. ${ }^{22}$ Endocarditis from disseminated infection can cause embolic strokes which could explain sudden onset diplopia, headache, and fever. ${ }^{22}$ Involvement of leptomeninges occurs in about $5 \%$ of patients with metastatic cancer and clinical manifestations are due to involvement of the cerebral hemispheres (headache), cranial nerves (diplopia), spinal cord, and exiting nerve roots (limb weakness, and bowel or bladder dysfunction). ${ }^{22,23}$ Lyme disease is a common tick-borne illness in the northeastern United States and, although rare, early lyme disease of the central nervous system can present as meningitis, cranial neuropathy, and radiculoneuropathy. ${ }^{2,24}$ Several other bacterial infections including syphilis, tuberculosis and fungal infections seem unlikely mainly due to the rapid onset of symptoms in our patient. Several features in the history (including history of outdoors work in the backyard, bug bites and presentation during falls) suggest an arboviral infection. Finally, autoimmune causes (myasthenia gravis, optic neuritis), inflammatory causes (neurosarcoidosis), vascular causes (stroke, aneurysm in posterior cerebral artery), vasculitic causes (temporal arteritis), and metabolic causes (thiamine deficiency) need to be considered in the differential diagnosis. 
In our patient, a normal ophthalmological and neurological examination, including extraocular eye movements, negative examination findings of MRI brain and computed tomography of orbits and sinuses, essentially ruled out some of the noninfectious causes of diplopia. Negative blood and cerebrospinal fluid cultures (before the initiation of antibiotics), a negative cerebrospinal fluid (CSF) gram stain, absence of leukocytosis in peripheral blood, and no vegetations in echocardiogram argue against a bacterial infection. Although the absence of pleocytosis in CSF made bacterial causes of meningitis unlikely, aseptic meningitis remained a concern because of high CSF protein. However, presentation of our patient during fall, history of bug bite, focal neurological sign, lymphopenia in complete blood count and relatively mild clinical presentation made West Nile virus infection a strong possibility, which was confirmed by immunoglobulin M (IgM) antibody measurements in CSF.

\section{Diagnosis of WNV infection}

The best test to verify WNV infection is measurement of IgM antibody in CSF, the sensitivity of which approaches $80 \%$ on the first sample. False negative results can be caused by hypogammaglobulinemia. ${ }^{25}$ Following exposure to WNV, both IgM and IgG antibodies are produced. In most cases, IgM antibodies can be detected within 4 to 7 days after the initial exposure and may persist for more than one year. ${ }^{26}$ IgM in CSF appears before it appears in serum and probably indicates a local production of antibody in the central nervous system rather than a transudation from systemic circulation. ${ }^{27}$ As the infection subsides, IgM antibody titers decrease whereas IgG antibodies remain. There is no specific treatment for West Nile virus.

\section{Treatment}

Since the treatment of WNV is mainly supportive, prevention of WNV infection should be a priority. Only by effective prevention can human morbidity and mortality be reduced. For effective prevention, the understanding of WNV transmission is important. During springtime, female Culex mosquitoes acquire WNV after feeding on birds, especially corvids (crows, magpies, and jays), which serve as a reservoir for WNV. ${ }^{13}$ Infected mosquitoes, by biting humans, help to spread the virus. ${ }^{13}$ Besides mosquitoes, blood transfusions, organ transplantations, and transplacental routes are also described as a mode of transmission, although they are rare. Higher summer temperatures increase the viral amplification, accelerating the enzootic cycle and increasing the subsequent chance of human exposure to infected mosquitoes. ${ }^{13}$ The new WNV genotype is also more pathogenic to birds (especially corvids) and investigation of corvid deaths have helped to track the spread of the virus. ${ }^{28}$ Educating the public about personal protection measures, like use of diethyltoluamide mosquito repellent when outdoors, use of protective clothing, and the elimination of standing water from individual yards could help prevent WNV infection. ${ }^{29}$

\section{Conclusion}

Physicians must remain alert for the less commonly described ocular symptoms and signs of WNV infection. Ocular features along with fever during WNV transmission season should alert the physician for a suspicion of WNV infection.

\section{Disclosure}

Authors report no conflicts of interest in this work.

\section{References}

1. Solomon T. Current concepts Flavivirus encephalitis. N Engl J Med. 2004;351(4):370-378.

2. Hirsch MS, DeMaria A Jr, Schaefer PW, Branda JA. Case records of the Massachusetts General Hospital. Case 22-2008. A 52-year-old woman with fever and confusion. N Engl J Med. 2008;359(3):294-303.

3. Centers for Disease Control and Prevention. [Webpage on the Internet]. Available at http://www.cdc.gov/ncidod/dvbid/westnile/surv\&control. htm. Accessed February 2, 2013.

4. Gubler DJ. The continuing spread of West Nile virus in the western hemisphere. Clin Infect Dis. 2007;45(8):1039-1046.

5. Bakri SJ, Kaiser PK. Ocular manifestations of West Nile virus. Curr Opin Ophthalmol. 2004;15(6):537-540.

6. Chan CK, Limstrom SA, Tarasewicz DG, Lin SG. Ocular features of West Nile virus infection in North America: a study of 14 eyes. Ophthalmology. 2006;113(9):1539-1546.

7. Bode AV, Sejvar JJ, Pape WJ, Campbell GL, Marfin AA. West Nile virus disease: a descriptive study of 228 patients hospitalized in a 4-county region of Colorado in 2003. Clin Infect Dis. 2006;42(9):1234-1240.

8. Garg S, Jampol LM. Systemic and intraocular manifestations of West Nile virus infection. Surv Ophthalmol. 2005;50(1):3-13.

9. Cinatl J Jr, Michaelis M, Fleckenstein C, et al. West Nile Virus infection induces intereferon signaling in human retinal pigment epithelial cells. Invest Ophthalmol Vis Sci. 2006;47(2):645-651.

10. Prasad S, Brown MJ, Galetta S. Transient downbeat nystagmus from West Nile virus encephalomyelitis. Neurology. 2006;66(10):1599-1600.

11. Priestley Y, Thiel M, Koevary SB. Systemic and ophthalmic manifestations of West Nile virus infection. Expert Rev Ophthalmol. 2008; 3(3):279-292.

12. Myers JP, Leveque TK, Johnson MW. Extensive chorioretinitis and severe vision loss associated with West Nile virus meningoencephalitis. Arch Ophthalmol. 2005;123(12):1754-1756.

13. Petersen LR, Hayes EB. West Nile virus in the Americas. Med Clin North Am. 2008;92(6):1307-1322.

14. Diamond MS, Klein RS. A genetic basis for human susceptibility to West Nile virus. Trends Microbiol. 2006;14(7):287-289.

15. Jeha LE, Sila CA, Lederman RJ, Prayson RA, Isada CM, Gordon SM. West Nile virus infection: A new acute paralytic illness. Neurology. 2003;61(1):55-59.

16. Ross JJ, Worthington MG. Bilateral sixth nerve palsy in West Nile meningoencephalitis. J Neuroophthalmol. 2004;24(1):97-98. 
17. Cunha BA, Eisenstein LE, Wirkowski E, Klein NH, Johnson DH. West Nile encephalitis relapse presenting with abducens and facial nerve palsies. Am J Med. 2006;119(6):e1-e2.

18. Pepperell C, Rau N, Krajden S, et al. West Nile Virus infection in 2002: Morbidity and mortality among patients admitted to hospital in southcentral Ontario. CMAJ. 2003;168(11):1399-1405.

19. Miller AH, Liang IE. Diplopia: a focal neurologic presentation of West Nile meningoencephalitis. Ann Emerg Med. 2003;42(3):413-416

20. Jensen MB. Diplopia secondary to West Nile virus meningitis. Webmedcentral. 2010;1(9):580.

21. Sampson BA, Armbrustmacher V. West Nile Encephalitis:the neuropathology of four fatalities. Ann N Y Acad Sci. 2001;(951): $172-178$

22. Wirth LJ, Plotkin SR, Emerick KS, Cunnane ME, Faquin WC. Case records of the Massachusetts General Hospital. Case 29-2012. A 49 year old man with pain and cranial nerve palsies after treatment of oral cancer. N Engl J Med. 2012;367(12):1136-1147.

23. Bomgaars L, Chamberlin MC, Poplack DG, Blaney M. Leptomeningeal metastases. In: Levin VA, editor. Cancer in the Nervous System, 2nd ed. New York: Oxford University Press; 2002:375-396.
24. Subak S. Effects of climate on variability in Lyme disease incidence in the northeastern United States. Am J Epidemiol. 2003;157(6): $531-538$.

25. Hollander H, Schaefer PW, Hedley-Whyte ET. Case records of the Massachusetts General Hospital. Case 22-2005. An 81-year-old man with cough, fever, and altered mental status. $N$ Engl J Med. 2005; 353(3):287-295.

26. De Filette M, Ulbert S, Diamond M, Sanders NN. Recent progress in West Nile Virus diagnosis and vaccination. Vet Res. 2012;43(1):16.

27. Tardei G, Ruta S, Chitu V, Rossi C, Tsai TF, Cernescu C. Evaluation of immunoglobulin $\mathrm{M}(\operatorname{IgM})$ and $\operatorname{IgG}$ enzyme immunoassays in serologic diagnosis of West Nile virus Infection. J Clin Microbiol. 2000;38(6):2232-2239.

28. Brault AC, Langevin SA, Bowen RA, et al. Differential virulence of West Nile strains for American crows. Emerg Infect Dis. 2004; 10(12):2161-2168.

29. Tyler KL. West Nile Virus infection in the United States. Arch Neurol. 2004;61(8):1190-1195.
International Journal of General Medicine

\section{Publish your work in this journal}

The International Journal of General Medicine is an international, peer-reviewed open-access journal that focuses on general and internal medicine, pathogenesis, epidemiology, diagnosis, monitoring and treatment protocols. The journal is characterized by the rapid reporting of reviews, original research and clinical studies across all disease areas.

\section{Dovepress}

A key focus is the elucidation of disease processes and management protocols resulting in improved outcomes for the patient.The manuscript management system is completely online and includes a very quick and fair peer-review system. Visit http://www.dovepress.com/ testimonials.php to read real quotes from published authors.

Submit your manuscript here: http://www.dovepress.com/international-journal-of-general-medicine-journal 